\title{
Biochar enriched with organic fertilizer improves the survival and growth rate of Anthocepalus cadamba seedlings planted on degraded spodosols
}

\author{
SYAHRINUDIN ${ }^{1, \bullet}$, WAHJUNI HARTATI ${ }^{1}$, TRIOYONO SUDARMADJI ${ }^{2}$, NURMAN KRISDIANTO ${ }^{1}$, \\ IBRAHIM ${ }^{1}$ \\ ${ }^{1}$ Laboratory of Silviculture Sciences, Faculty of Forestry, Universitas Mulawarman. J1. Ki Hajar Dewantara, Gunung Kelua, Samarinda 75123, \\ East Kalimantan, Indonesia. Tel.: +62-541-735089, Fax.: +62-541-735379, ^email: syahri@ymail.com \\ ${ }^{2}$ Laboratory of Soil and Water Conservation, and Climate, Faculty of Forestry, Universitas Mulawarman. Jl. Ki Hajar Dewantara, Gunung Kelua, \\ Samarinda 75123, East Kalimantan, Indonesia
}

Manuscript received: 2 October 2019. Revision accepted: 26 November 2019.

\begin{abstract}
Syahrinudin, Hartati W, Sudarmadji T, Krisdianto N, Ibrahim. 2019. Biochar enriched with organic fertilizer improves the survival and growth rate of Anthocepalus cadamba seedlings planted on degraded spodosols. Biodiversitas 20: 3741-3750. The application of biochar for the improvement of soil properties and fertility has drawn enormous interest worldwide nowadays and numerous application options are now available. This research was aimed to evaluate the effects of the application of biochar and organic fertilizers on the survival and growth of Anthocepalus cadamba seedlings planted on degraded spodosols soil on bioassay trial in the nursery. Bioassay trial was carried out in the nursery of Faculty of Forestry, Mulawarman University, Samarinda, Indonesia, employing a 2-factors Completely Randomized Design (CRD) with factor 1 was the rate of biochar application (i.e. six levels of treatment: 0 (control), 2, 5, 10, 25 and 100\%v of biochar), and factor 2 (enrichment of organic fertilizers, i.e. with enrichment and without enrichment), and each treatment combination had 3 replications. The results showed that biochar application alone improved height and diameter growth rate of $A$. cadamba seedlings by $253 \%$ and $116 \%$ of control treatment (without biochar), respectively. Enrichment of organic fertilizers gave further improvement in height and diameter growth rate of $A$. cadamba seedlings to $386 \%$ and $150 \%$ of control treatment (without biochar), respectively. Furthermore, biochar application improved survival and biomass growth rate of the seedlings. Enrichment of organic fertilizers into biochar improved not only seedling growth rate but also more interestingly the carrying capacity of spodosols to biochar application rate. We concluded that biochar application complemented with enrichment of organic fertilizers on spodosols is highly promising for the improvement of both soil carbon sequestration and plant growth performance.
\end{abstract}

Keywords: Anthocepalus cadamba, biochar, enrichment, growth, spodosol

\section{INTRODUCTION}

Climate change and global warming are among the most challenging environmental, economic and social issues worldwide. Carbon dioxide $\left(\mathrm{CO}_{2}\right)$, one of the most prominent anthropogenic-induced greenhouse gases, contributes to more than $51 \%$ of global warming. The level of atmospheric $\mathrm{CO}_{2}$ has increased substantially, resulting in its content of about $760 \mathrm{Pg}$ of carbon $(\mathrm{C})$ as $\mathrm{CO}_{2}$ (Schimel 1995; IPCC 2000). However, atmospheric $C$ represents less than $30 \%$ of the $\mathrm{C}$ in terrestrial ecosystems. Vegetation contains nearly $500 \mathrm{Pg} \mathrm{C}$, while soils contain another 2000 $\mathrm{Pg} \mathrm{C}$ in the form of organic matter and detritus (Schimel 1995; IPCC 2000). Regardless the debate as to whether global forests are sources or sinks of greenhouse gases (Ravindranath et al. 1997; Lal and Singh 2000; Harmon 2001; Metting et al. 2001; Schimel et al. 2001; Pelley 2003), managed fast-growing forests may enhance C sequestration (Papadopol 2000; Metting et al. 2001; Lee et al. 2002; Ney et al. 2002).

There are great opportunities for mitigation of further increases in the atmospheric $\mathrm{C}$ pool in forestry (IPCC
2001). Forest-C sequestration has been identified as one of the most promising options to reduce the build-up of atmospheric $\mathrm{CO}_{2}$ (Dixon et al. 1993; Sampson and Sedjo 1997; Marland and Schlamadinger 1999). Silvicultural strategies aiming at accelerating the stand growth are likely to increase the rate of $\mathrm{C}$ sequestration of the respective forests (Montagnin and Porras 1998; Chen et al. 2000; Lee et al. 2002; Budiharta et al. 2014). In respect of soil organic carbon (SOC) sequestration, afforestation and reforestation including tree planting through agroforestry, are the only land-based negative emissions (i.e. removing $\mathrm{CO}_{2}$ from the atmosphere) which are readily available at low cost (Smith et al. 2016). Soils carry a significant potential for carbon sequestration, especially through restoration measures on degraded soils (Lal 2010) and biochar application may further increase SOC carrying capacity of the systems (Lehmann 2007; Lu et al. 2014; Luo et al. 2014).

Spodosols are common in the lowlands of the tropics (Roslan et al. 2010), forming from very sandy parent materials (Japony and Tan 1989); they are formed by the process of podzolization leading to the presence of spodic horizon, an illuvial layer with spodic materials (organic 
matter and/or oxides complexes) overlain by an albic horizon (Buurman and Jongmans 2004). Spodic materials are associated with vertical movement of organo-Al and/or Fe oxides complex (Wilson and Righi 2010). Soil grain dominated by quartz sand fraction (Roslan et al. 2010) coupled with low soil pH and CEC (Roslan et al. 2011) leads to low water holding capacity and low nutrient retention, resulting in limited land uses in spodosols. The occurrence of frequent flooding (Soil Survey Staff 1996) further limits utilization of these soils. Natural vegetation occupied such soils mostly heat forests (Davies and Becker 1996) and any disturbance to such forest leads to ecosystem and soil degradation (Becker 2006). Since there are many limitations on the cultivation of degraded spodosols, only limited number of species could be planted.

Anthocepalus cadamba-an early-succession species which grows best on deep, moist, alluvial sites, often in secondary forests along riverbanks and in the transitional zone between swampy, permanently flooded and periodically flooded areas (Soerianegara and Lemmens 1993)-is a promising species to cultivate on such soils. However, measures should be handled carefully to make the success of plantation in such soils. Therefore, the management of soil organic matter and plant nutrition are considered of utmost importance.

The world-wide tremendous increase of interest in biochar application in the last few decades is driven by the long-term multi-benefits given by the applications. Regardless the debate on the magnitude, uncertainties and residence time effects, biochar application promotes the improvement of water and nutrient retention (Glaser et al. 2002; Liang et al. 2006; Chan et al. 2007; Steiner et al. 2007); soil microbial biomass, activities and structures ( $\mathrm{Yu}$ et al. 2018; Lehmann et al. 2011; Thies and Rillig 2009); fertilizer and nutrient use efficiency (DeLuca et al. 2009; Schulz and Glaser 2012); soil physical properties (Atkinson et al. 2010; Mukherjee and Lal 2013); immobilization of toxic substances in soils (Rees et al. 2015; Rizwan et al. 2015); plant growth and productivity (Carter et al. 2013; Cornelissen et al. 2013; William and Qureshi 2015; Liu et al. 2016; Syahrinudin et al. 2018); plant drought and salinity resistance (Akhtar et al. 2015; Kim et al. 2016; Ali et al. 2017; Egamberdieva et al. 2017; Farhangi-Abriz and Torabian 2017); plant toxicity resistance (Zheng et al. 2012; Gartler et al. 2013; Rees et al. 2015; Rizwan et al. 2015); plant disease resistance (Huang et al. 2015; Mehari et al. 2015); nitrous oxide and methane emission reduction (Rondon et al. 2005; Yanai et al. 2007; Spokas et al. 2009); and soil carbon pool (Lehmann 2007; Lu et al. 2014; Luo et al. 2014).

Application of biochar coupled with nutrient enrichment on degraded and heavily weathered soils in the tropics would be beneficial in terms of both SOC sequestration and crop production. Liquid organic fertilizer could improve the effectiveness of biochar application. Liquid organic fertilizers consist of essential plant nutrients and beneficial microorganisms, thus it could maintain soil sustainability and plant health (Dordas et al. 2007; Hou et al. 2017). Furthermore, compounds in liquid organic fertilizers, such as chitin, humic and fulvic acids, and other biopolymers, can be biostimulants to plants (Sharp 2013; Canellas et al. 2015). This study was devoted to evaluate the effects of the application of biochar and organic fertilizers on the survival and growth of Anthocepalus cadamba seedlings planted on spodosols soil at pot level.

\section{MATERIALS AND METHODS}

\section{Study area and period}

Growth media preparation, including arrangement and tests, was carried out at Soil Science Laboratory and Soil and Water Conservation Laboratory, Faculty of Forestry, Mulawarman University, Samarinda, Indonesia. Bioassay test for Anthocepalus cadamba seedlings was carried out at the nursery of the Faculty of Forestry, Mulawarman University. Research period was three months observation, after replanting the seedlings following the pre-observation works, biochar and liquid organic fertilizer production, soil media collection and nursery preparation for period of two months.

\section{Procedure}

Biochar production and media preparation

Spodosols soil used for the growth media of this research was collected from nearby degraded spodosols soil, $40 \mathrm{~km}$ northeast of Samarinda. These soils were very coarse in texture, very low in water holding capacity and nutrient retention (Prasetyo et al. 2006) while biochar used was produced based on retort biochar production method (Figure 1). Raw materials for the biochar production were wood of stem and branches of Vitex pinnata wastes derived from adjacent plantations. The raw materials were loaded into kiln drum, the kiln was then closed tightly to avoid air penetration, heated with external fuel, in this case liquid natural gas, till the production of gases from the heated materials. Thereafter, supply of external fuel was terminated, and further heating of the feedstock relied solely on the gases released by the materials. Once the produced gases were exhausted, the biochar production was completed. Peak production temperatures were about 400$500^{\circ} \mathrm{C}$ for period of 30 minutes to one hour.
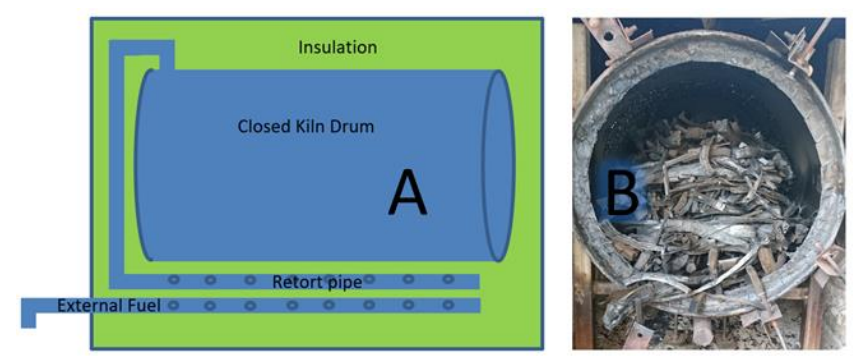

Figure 1. Schematic of closed drum retort kiln biochar production (A) and biochar produced with closed drum retort kiln (B) 
Table 1. Selected properties of biochar with and without enrichment of nutrients

\begin{tabular}{lcc}
\hline \multicolumn{1}{c}{ Properties } & $\begin{array}{c}\text { Without } \\
\text { enrichment }\end{array}$ & $\begin{array}{c}\text { With } \\
\text { enrichment }\end{array}$ \\
\hline $\mathrm{pH} \mathrm{H} \mathrm{H}_{2} \mathrm{O}$ & 7.14 & 6.1 \\
$\mathrm{pH} \mathrm{KCl}$ & 6.61 & 5.9 \\
Nitrogen $(\%)$ & 1.56 & 3.05 \\
Available $\mathrm{P}(\mathrm{ppm})$ & 82.11 & 105.02 \\
Available K $(\mathrm{ppm})$ & 572.53 & 589.59 \\
\hline
\end{tabular}

Biochar was ground to powder to pass a 2-mm-sieve prior to nutrient enrichment and mixing with soils. The nutrient enrichment of biochar was processed by inundating dry-fine biochar with liquid organic fertilizer for one hour prior to the mixing with soils. Liquid organic fertilizer used in this work was derived from anaerobic fermentation of vegetable wastes of local traditional market. The mixtures were then filled into polyethylene pots $(10 \mathrm{~cm}$ diameter and $15 \mathrm{~cm}$ height), watered and kept overnight prior to the transplanting of seedlings. Selected properties of enriched-and without enrichment biochar are presented in Table 1.

\section{Experimental design}

Biochar application in this research was prepared to comply with a 2-factors (biochar application rate and nutrient enrichment) Completely Randomized Design procedure. Six levels of biochar application for growth media were arranged, those are $0 \% \mathrm{v}, 2 \% \mathrm{v}, 5 \%, 10 \% \mathrm{v}$, $25 \% \mathrm{v}$, and $100 \% \mathrm{v}$ and two levels of nutrient enrichment, i.e.: liquid organic fertilizer enrichment and without enrichment. Treatment was replicated three times, each consisted of 20 seedlings, thus this research involved 720 seedlings of $A$. cadamba. Low levels of biochar treatment were established to evaluate the importance of biochar treatment in promoting plant growth on degraded spodosols soils, whereas high-level biochar treatment was established to evaluate the possibility of the using of biochar as major media for plant growth in nursery.

\section{Data measurement and analysis}

The effect of biochar treatment on the growth of $A$. cadamba seedlings was assessed by the increment of the height, diameter and biomass of seedlings. Height of seedlings was measured weekly and diameter and biomass of seedlings were measured at the end of the research period, 3 months after replanting. However, survival of seedlings was also recorded weekly.

Data collected in this research were tested and adjusted to normal distribution (Vasicek 1976) prior to analysis of variance (Fisher 1919) and mean different tests (Fisher 1935) with the help of SPSS software.

\section{RESULTS AND DISCUSSION}

Environmental factors, such as light, moisture, nutrients, density, and temperature (Chapin et al. 1987;
Chen et al. 2015), and plant physiological factors, including carbohydrate reserves, hormone levels, and dormancy (George et al. 2008), work together in defining the growth and survival of seedlings. Biochar may alter environmental conditions of seedlings in such ways to give better conditions for the improvement of growth, survival, and quality of the seedlings (Dharmakeerthi et al. 2012; Haider et al. 2017). The survival of A. cadamba seedlings was calculated as ratio of number of life seedlings to the number of those at the start of the study. Table 2 shows the survival of seedlings at the end of the study. At the full range of biochar application level, ranging from $0 \%$ to $100 \%$, nor biochar application rate neither treatment interaction gave significant effect on the survival rate of seedlings studied, nevertheless application of lower rate biochar promoted higher survival of seedlings as compared to that of control, $0 \%$ biochar application. In contrast to biochar application rate, nutrient enrichment gave significant effect on the survival rate of the seedlings studied, $\mathrm{p}=0.02$.

Nutrient enriched biochar promoted higher survival rate at all rates of biochar treatment (Table 2). These results suggest that the application of biochar soil amendment coupled with other materials such as fertilizer, sludge and composted organic wastes would further enhance the favorable conditions of plant growth media (Alburquerque et al. 2013; Schimmelpfennig et al. 2014; Marjenah et al. 2016). The addition of these materials into biochar application may further improve nutrient availability, i.e. nitrogen, phosphorus, potassium, calcium, magnesium, and micronutrients (Alburquerque et al. 2013; Gondek et al. 2018). Sludge and composted organic wastes may enhance not only nutrient availability but also biological structure and diversity of media (Luo et al. 2018). However, all treatments gave high survival rate, more than $90 \%$, including that of $100 \%$ biochar treatment. Biochar application on growth media in nursery also gave high survival for Dipterocarps seedlings (Marjenah et al. 2016; Syahrinudin et al. 2018). These demonstrate that the use of biochar as main media for raising seedlings in nursery is of interest for the replacement of the conventional media as the availability of these conventional media (topsoils) becoming scarce lately and the use of these conventional media subject to ecological degradation of its originremoving fertile topsoil from the system may lead to nutrient cycle disruption and nutrient shortage of the system. The importance of biochar on plant survival is mostly driven by the improvement of plant water availability, aeration, porosity, nutrient retention and holding capacity to promote optimum utilization of root zone resources. Moreover, biochar application leads to the improvement of plant tolerance to salinity (Ali et al. 2017; Farhangi-Abriz and Torabian 2017; Kim et al. 2016), resistant on diseases (Mehari et al. 2015; Huang et al. 2015), drought-resistant (Kammann et al. 2011; Haider et al. 2014; Ali et al. 2017; Egamberdieva et al. 2017) and heavy metals and toxic elements resistance (Zheng et al. 2012; Gartler et al. 2013; Rizwan et al. 2015; Rees et al. 2015). 
Table 2. Survival of 3-months-old seedlings after treatments (mean values followed by different letters are significant at $p<$ 0.05; 0 and 1 in enrichment column represent without and with nutrient enrichment, respectively
Table 3. Height of 3-months-old seedlings after treatment (mean values followed by different letters are significant at $\mathrm{p}<0.05 ; 0$ and 1 in enrichment column represent without and with nutrient enrichment, respectively

\begin{tabular}{|c|c|c|c|c|c|c|c|c|c|}
\hline \multicolumn{3}{|c|}{ Treatment } & \multicolumn{2}{|c|}{ Survival } & \multicolumn{3}{|c|}{ Treatment } & \multicolumn{2}{|c|}{ Seedling height } \\
\hline Code & Biochar & Enrichment & Mean & STD & Code & Biochar & Enrichment & Mean & STD \\
\hline \multicolumn{3}{|c|}{$\begin{array}{c}(\% \mathrm{v}) \\
\text { Interaction }(\mathrm{A} \times \mathrm{x})\end{array}$} & \multicolumn{2}{|c|}{$\%$} & \multicolumn{3}{|c|}{$\begin{array}{l}(\% \mathrm{v}) \\
\text { Interaction }(\mathrm{A} \times \mathrm{B})\end{array}$} & \multicolumn{2}{|c|}{$\mathbf{c m}$} \\
\hline $\mathrm{A} 0 \mathrm{~B} 0$ & 0 & 0 & 97.0 & 0.02 & A0B0 & 0 & 0 & $6.2^{\mathrm{ab}}$ & 1.2 \\
\hline A0B1 & 0 & 1 & 97.0 & 0.02 & $\mathrm{~A} 0 \mathrm{~B} 1$ & 0 & 1 & $6.2^{\mathrm{ab}}$ & 1.2 \\
\hline $\mathrm{A} 1 \mathrm{~B} 0$ & 2 & 0 & 98.0 & 0.02 & $\mathrm{~A} 1 \mathrm{~B} 0$ & 2 & 0 & $13.6^{\mathrm{bc}}$ & 4.2 \\
\hline A1B1 & 2 & 1 & 100.0 & 0.00 & A1B1 & 2 & 1 & $13.2^{\mathrm{bc}}$ & 2.5 \\
\hline $\mathrm{A} 2 \mathrm{~B} 0$ & 5 & 0 & 98.0 & 0.02 & $\mathrm{~A} 2 \mathrm{~B} 0$ & 5 & 0 & $9.7^{\mathrm{b}}$ & 1.0 \\
\hline $\mathrm{A} 2 \mathrm{~B} 1$ & 5 & 1 & 100.0 & 0.00 & $\mathrm{~A} 2 \mathrm{~B} 1$ & 5 & 1 & $14.7^{\mathrm{c}}$ & 2.3 \\
\hline $\mathrm{A} 3 \mathrm{~B} 0$ & 10 & 0 & 93.0 & 0.05 & $\mathrm{~A} 3 \mathrm{~B} 0$ & 10 & 0 & $15.7^{\mathrm{c}}$ & 0.7 \\
\hline A3B1 & 10 & 1 & 98.0 & 0.02 & A3B1 & 10 & 1 & $23.1^{\mathrm{d}}$ & 2.6 \\
\hline $\mathrm{A} 4 \mathrm{~B} 0$ & 25 & 0 & 93.0 & 0.05 & $\mathrm{~A} 4 \mathrm{~B} 0$ & 25 & 0 & $10.6^{b}$ & 3.4 \\
\hline $\mathrm{A} 4 \mathrm{~B} 1$ & 25 & 1 & 98.0 & 0.02 & $\mathrm{~A} 4 \mathrm{~B} 1$ & 25 & 1 & $23.9^{d}$ & 3.0 \\
\hline $\mathrm{A} 5 \mathrm{~B} 0$ & 100 & 0 & 92.0 & 0.07 & $\mathrm{~A} 5 \mathrm{~B} 0$ & 100 & 0 & $4.8^{\mathrm{a}}$ & 1.5 \\
\hline A5B1 & 100 & 1 & 98.0 & 0.02 & A5B1 & 100 & 1 & $17.1^{\mathrm{c}}$ & 1.4 \\
\hline \multicolumn{5}{|c|}{ Factor A (Rate of biochar) } & \multicolumn{3}{|c|}{ Factor A (Rate of biochar) } & & \\
\hline A0 & 0 & - & 97.0 & 0.02 & A0 & 0 & - & $6.2^{\mathrm{a}}$ & 1.1 \\
\hline A1 & 2 & - & 99.0 & 0.01 & A1 & 2 & - & $13.4^{\mathrm{b}}$ & 7.3 \\
\hline $\mathrm{A} 2$ & 5 & - & 99.0 & 0.01 & $\mathrm{~A} 2$ & 5 & - & $12.2^{\mathrm{b}}$ & 3.2 \\
\hline A3 & 10 & - & 95.5 & 0.04 & A3 & 10 & - & $19.4^{\mathrm{c}}$ & 4.4 \\
\hline A4 & 25 & - & 95.5 & 0.04 & A4 & 25 & - & $17.3^{\mathrm{c}}$ & 7.8 \\
\hline A5 & 100 & - & 95.0 & 0.05 & A5 & 100 & - & $10.9^{\mathrm{b}}$ & 6.9 \\
\hline \multicolumn{5}{|c|}{ Factor B (Enrichment) } & \multicolumn{3}{|c|}{ Factor B (Enrichment) } & & \\
\hline B0 & - & 0 & $95^{\mathrm{a}}$ & 2.8 & B0 & - & 0 & $10.1^{\mathrm{a}}$ & 4.4 \\
\hline $\mathrm{B} 1$ & - & 1 & $99^{\mathrm{b}}$ & 1.2 & $\mathrm{~B} 1$ & - & 1 & $16.4^{\mathrm{b}}$ & 6.5 \\
\hline
\end{tabular}

The environment is a complex of so many factors interrelated, soil is vitally important for plant growth and development. Soil represents a complicated physical, chemical, and biological system by which the plant is supplied with the water, nutrients, and oxygen. Biochar amendment may improve the physical properties of soil, i.e. bulk density, porosity, water holding capacity, available water, infiltration, permeability, structure formation and stability (Herath et al. 2013; Darusman et al. 2017; Mahmoud et al. 2017), chemical properties, i.e. increased the $\mathrm{pH}, \mathrm{CEC}$, nutrient retention (Hossain et al. 2010; Silber et al. 2010; Fernandes et al. 2018) and biological properties, i.e. microbial population and activities, microbial structure (Graber et al. 2010; Kolton et al. 2011; Luo et al. 2018) to promote better use of plant root zone which in turn enhance plant growth and quality.

The average plant height increased in line with the age of the plant till the end of observation period ( 3 months after replanting). The difference in the height of plants among biochar application levels also increased with age. At the end of the observation period, three months after replanting, excluding the height of seedlings planted on growth media of $100 \%$ biochar treatment, the average height of plants in all media receiving biochar treatment was higher than that without biochar (Table 3), with application of $25 \% \mathrm{v}$ enriched biochar gave the highest seedlings height, $\mathrm{p}<0.01$.

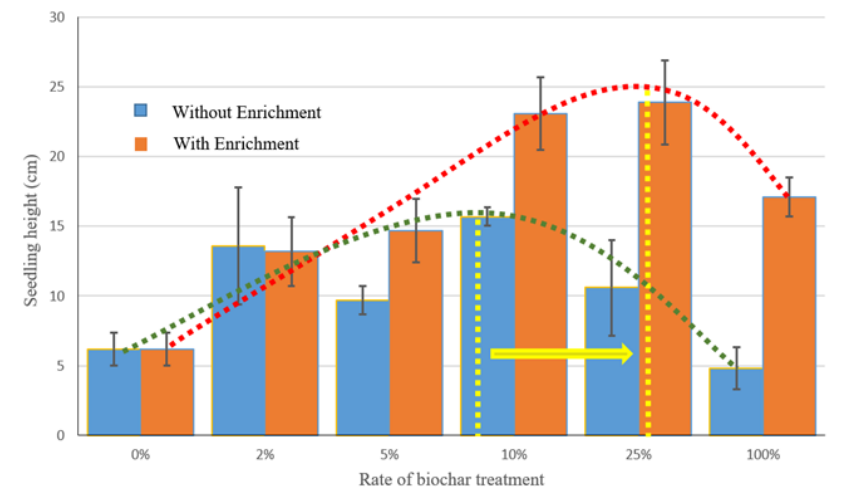

Figure 2. The effect of biochar application and nutrient enrichment of the height of seedlings. Stack bars represent standard deviations of the respective means

Biochar alone (without nutrient enrichment) improved the growth rate of seedlings by $253 \%$ compared to the control treatment (without biochar) at application rate of $10 \% \mathrm{v}$ biochar, enrichment of biochar lifted up effect of biochar application on height growth rate of seedling to $386 \%$ compared to the control treatment at application rate of $25 \%$ of biochar (Figure 2). It is interesting that enriched biochar not only improved the growth rate response but also carrying capacity of soils to biochar treatment from about $10 \% \mathrm{v}$ to somewhere around $25 \% \mathrm{v}$ (Figure 2). 
Biochar modifies the environmental conditions of the growing media through improvement of aeration, water availability attributed to its high porosity and low bulk density (Abel et al 2013; Herath et al 2013; Pratiwi and Shinogi 2016), soil reactions, microorganism activity in the soil and availability of plant nutrients attributed its chemical properties, i.e. high surface area, liming effect and nutrient content of biochar (Major et al. 2010; Dharmakeerthi et al. 2012) to facilitate the optimal utilization of the resources of plant roots environment which in turn will increase plant growth. However, at higher biochar applications (i.e. $25 \% \mathrm{v}$ and $100 \% \mathrm{v}$ ), height growth rate of $A$. cadamba seedlings decreased, which may be attributed to the nutrient immobilization by microorganisms consuming volatile matter in biochar (Sun et al. 2015; Kanouo et al. 2017). Figure 2 implies that application of enriched biochar may further improve soil carbon sequestration potential to more than two-fold of that of without enrichment. Soil organic carbon (SOC) is the main factor affecting soil quality and agriculture sustainability. Being a source and sink of plant nutrients, SOC plays an important role in terrestrial $\mathrm{C}$ and nutrient cycle (Freixo et al. 2002). Carbon sequestrations in agricultural soils is of significant importance for atmospheric carbon dioxide mitigation and soil fertility enhancement (Glaser et al. 2002; Lehmann 2007). Traditional soil organic carbon (SOC) enrichment practices involving biomass residues incorporation and green manures lead to rapid mineralization releasing $\mathrm{CO}_{2}$ to atmosphere (Sauerbeck 2001; Lehmann et al. 2006; Baker et al. 2007; Bruun et al. 2011) beside subject to the enhancement of methane and nitrous oxide emission (Palumbo et al. 2004; Reijnders 2009) contributing to higher global warming potential. In contrast to traditional organic materials, biochar is a highly carbonized material produced by pyrolysis, consisting of large extent of aromatic compounds that are resistant to biological degradation (Baldock and Smernik 2002). Biochar may stay in soils for hundreds to thousands of years (Lal 2003; Kuzyakov et al. 2009). Therefore, biochar application is a promising alternative to sequester more $\mathrm{C}$ in soils compared to traditional practices and rated as the best geoengineering option for carbon sequestration (Lenton and Vaughan 2009). Large-scale biochar application will lead to the increase of soil carbon pool contributing to climate change mitigation (Ameloot et al. 2013).

Diameter growth rate of $A$. cadamba seedlings showed similar manner to that of height growth rate, but less pronounce and higher preference to biochar application level (Table 4). Both factors, rate of biochar treatment and biochar enrichment, as well as the interaction gave significant effect on diameter growth rate of A. cadamba seedlings grown in spodosols in pots experiment. At the end of the observation period, three months after replanting, the average diameter of plants in all media receiving biochar treatment was higher than that without biochar, with application of $25 \% \mathrm{v}$ biochar gave highest seedlings diameter, $\mathrm{p}<0.01$. Growth rate of seedling diameter showed positive response to wide range of biochar application level. Biochar alone improved growth
Table 4. Diameter of 3-months-old seedlings after treatment (mean values followed by different letters are significant at $\mathrm{p}<$ 0.05 ; 0 and 1 in enrichment column represent without and with nutrient enrichment, respectively

\begin{tabular}{|c|c|c|c|c|}
\hline \multicolumn{3}{|c|}{ Treatment } & \multicolumn{2}{|c|}{ Seedling diameter } \\
\hline Code & Biochar & Enrichment & Mean & STD \\
\hline \multicolumn{3}{|c|}{$\begin{array}{c}(\% \mathrm{v}) \\
\text { Interaction }(\mathrm{A} \times \mathrm{x})\end{array}$} & \multicolumn{2}{|c|}{$\mathbf{m m}$} \\
\hline A0B0 & 0 & 0 & $2.11^{\mathrm{a}}$ & 0.02 \\
\hline $\mathrm{A} 0 \mathrm{~B} 1$ & 0 & 1 & $2.11^{\mathrm{a}}$ & 0.02 \\
\hline A1B0 & 2 & 0 & $2.14^{\mathrm{a}}$ & 0.05 \\
\hline A1B1 & 2 & 1 & $2.37^{\mathrm{b}}$ & 0.10 \\
\hline $\mathrm{A} 2 \mathrm{~B} 0$ & 5 & 0 & $2.12^{\mathrm{a}}$ & 0.11 \\
\hline $\mathrm{A} 2 \mathrm{~B} 1$ & 5 & 1 & $2.44^{b}$ & 0.05 \\
\hline $\mathrm{A} 3 \mathrm{~B} 0$ & 10 & 0 & $2.16^{\mathrm{ab}}$ & 0.23 \\
\hline $\mathrm{A} 3 \mathrm{~B} 1$ & 10 & 1 & $2.80^{\mathrm{c}}$ & 0.13 \\
\hline $\mathrm{A} 4 \mathrm{~B} 0$ & 25 & 0 & $2.44^{b}$ & 0.14 \\
\hline $\mathrm{A} 4 \mathrm{~B} 1$ & 25 & 1 & $3.10^{\mathrm{d}}$ & 0.12 \\
\hline $\mathrm{A} 5 \mathrm{~B} 0$ & 100 & 0 & $2.14^{\mathrm{a}}$ & 0.47 \\
\hline $\mathrm{A} 5 \mathrm{~B} 1$ & 100 & 1 & $3.17^{\mathrm{d}}$ & 0.04 \\
\hline \multicolumn{5}{|c|}{ Factor A (rate of biochar) } \\
\hline A0 & 0 & - & $2.11^{\mathrm{a}}$ & 0.02 \\
\hline A1 & 2 & - & $2.26^{\mathrm{a}}$ & 0.95 \\
\hline $\mathrm{A} 2$ & 5 & - & $2.28^{\mathrm{ab}}$ & 0.19 \\
\hline $\mathrm{A} 3$ & 10 & - & $2.48^{\mathrm{b}}$ & 0.39 \\
\hline A4 & 25 & - & $2.77^{\mathrm{c}}$ & 0.38 \\
\hline A5 & 100 & - & $2.65^{\mathrm{bc}}$ & 0.64 \\
\hline \multicolumn{5}{|c|}{ Factor B (enrichment) } \\
\hline B0 & - & 0 & $2.19^{\mathrm{a}}$ & 0.22 \\
\hline B1 & - & 1 & $2.66^{\mathrm{b}}$ & 0.41 \\
\hline
\end{tabular}

rate of seedlings diameter by $116 \%$ compared to the control treatment (without biochar) at application rate of $25 \% \mathrm{v}$ biochar. The application of biochar may significantly increase the soil $\mathrm{pH}$ towards neutralize and reduce soil exchangeable acidity (Xu et al. 2012; Yuan et al. 2011). During the pyrolysis of biomass materials, most of the micro-and macronutrients were segregated into biochar fractions. When it is applied to the acid soils, the basic cation, especially $\mathrm{Ca}^{2+}$, can exchange with $\mathrm{Al}^{3+}$ and $\mathrm{H}^{+}$on the soil exchange sites. Due to these mechanisms, soil exchangeable acidity is reduced while soil exchangeable basicity (basic cations) is enhanced (Lehmann et al. 2003). Growth improvement of seedlings may also be attributable to the pore distribution improvement of growth media. Positive effect of biochar on soil bulk density is mainly the result of the dilution effect of biochar having higher porosity and soil aggregation (Mukome et al. 2013; Zong et al. 2014).

Enrichment of biochar lifted up the effect of biochar application on diameter growth rate of seedlings to $150 \%$ of the control treatment at application rate of $100 \%$ of biochar. It is interesting that enriched biochar not only improves growth rate response but also carrying capacity of soils to biochar treatment from about $25 \% \mathrm{v}$ to $100 \% \mathrm{v}$. The applications of liquid organic fertilizers may significantly improve the nutrient level, i.e. mineral $\mathrm{N}$, available $\mathrm{P}$, and available $\mathrm{K}$ contents ( $\mathrm{Ji}$ et al. 2017) attributed to the 
improved diversity of the microbial community, which enhances the nutrient cycle in the soil (Lee et al. 2004; Zhu et al. 2013). Even though the diameter growth rate response of A. cadamba seedlings to application of $100 \%$ biochar treatment alone was less pronounced, the enrichment of nutrients into biochar gave tremendous improvement in diameter growth rate of seedlings. Here again, our results suggested that the use of biochar for major plant growth media in raising seedling in nursery is promising.

Biomass growth rate of $A$. cadamba seedlings showed similar manner to that of diameter growth rate, but in contrast to height growth rate, biomass growth rate showed good preference to higher rate of biochar application-level especially for those with enrichment (Figure 3). Both factors, rate of biochar treatment and nutrient enrichment gave significant effect on biomass growth rate of $A$. cadamba seedlings grown in spodosols in pots experiment. However, interaction of the treatments gave significant effect as well. At the end of the observation period, three months after replanting, excluding the application of $100 \%$ biochar without enrichment, the average of plant biomass in all media receiving biochar treatment was higher than that without biochar with application of $100 \% \mathrm{v}$ biochar gave the highest seedlings biomass, $\mathrm{p}<0.01$. In line with diameter growth rate, growth rate of seedling biomass showed positive response to wide range of biochar application levels. Biochar alone improved growth rate of seedlings shoot and root biomass by $124 \%$ and $168 \%$ of the control treatment (without biochar) at application rate of $15 \% \mathrm{v}$ and $10 \%$ biochar, respectively. Enrichment of organic nutrients into biochar lifted up the effect of biochar application on shoot and root biomass growth rate of seedling to $214 \%$ and $364 \%$ of the control treatment at application rate of $100 \%$ of biochar, respectively. Response of seedling biomass growth rate to enriched biochar application confirmed that of height and diameter growth rate of seedlings that enriched biochar not only improved growth rate but also carrying capacity of soils to biochar treatment from about $15 \% \mathrm{v}$ to $100 \% \mathrm{v}$. In the similar ways as to diameter growth rate, the response of A. cadamba seedlings to application of biochar treatment alone was less pronounce, biochar enriched with organic fertilizers gave tremendous improvement in biomass growth rate of seedlings. Regression analysis showed that there is high dependency of root biomass growth rate on the application rate of enriched biochar $\left(r^{2}=0.98, p<0.01\right)$, and shoot biomass growth rate of all treatment highly correlated to the root biomass growth rate of the seedling $\left(r^{2}=0.74, p<\right.$ 0.01 ), thus the overall biomass growth rate was highly affected by biochar application. This may imply that the use of biochar for major plant growth media in raising seedling in nursery is promising.

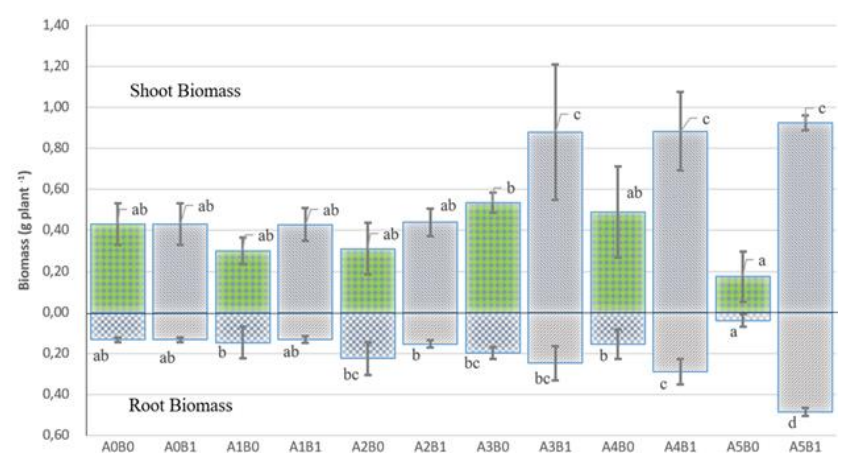

Figure 3. Biomass growth rate response of seedlings to biochar application; A0, A1, A2, A3, A4, and A5 represent biochar application of $0 \% \mathrm{v}, 2 \% \mathrm{v}, 5 \% \mathrm{v}, 10 \% \mathrm{v}, 25 \% \mathrm{v}$ and $100 \% \mathrm{v}$, respectively; B0 and B1 represent without nutrient enrichment and with nutrient enrichment, respectively; stack bars are standard deviations of the respective means.

In conclusion, biochar application on degraded spodosols is of utmost interest not only driven by soil organic carbon sequestration potential of biochar in such ecosystems but also by the amendment capacity of biochar to improve soil fertility and facilitate favorable root zone conditions for optimum utilization by plants. Biochar application alone improved height and diameter growth rate of $A$. cadamba seedlings by $253 \%$ and $116 \%$ of control treatment (without biochar), respectively. Enrichment of organic fertilizers gave further improvement in height and diameter growth rate of $A$. cadamba seedlings to $386 \%$ and $150 \%$ of control treatment (without biochar), respectively. Furthermore, biochar application improved survival and biomass growth rate of the seedlings. Enrichment of organic fertilizers into biochar improved not only seedling growth rate but also more interestingly carrying capacity of spodosols to biochar application rate. Therefore, a lot more biochar could be applied to such soils and higher atmospheric carbon dioxide mitigation could be achieved. This study suggests that the use of biochar enriched with organic fertilizers as media to grow seedling in nursery is promising.

\section{ACKNOWLEDGEMENTS}

This work was funded by Ministry of Research, Technology and Higher Education of Indonesia.

\section{REFERENCES}

Abel S, Peters A, Trinks S, Schonsky H, Facklam M, Wessolek G. 2013. Impact of biochar and hydrochar addition on water retention and water repellency of sandy soil. Geoderma 202: 183-191.

Akhtar SS, Andersen MN, Liu F. 2015. Biochar mitigates salinity stress in potato. J Agron Crop Sci 201: 368-378.

Alburquerque JA, Salazar P, Barrón V, Torrent J, del Carmen del Campillo M, Gallardo A, Villar R. 2013. Enhanced wheat yield by biochar addition under different mineral fertilization levels. Agron Sustain Dev 33: 475-484. 
Ali S, Rizwan M, Qayyum MF, Ok YS, Ibrahim M, et al. 2017. Biochar soil amendment on alleviation of drought and salt stress in plants: a critical review. Environ Sci Pollut Res 24: 12700-12712. DOI: 10.1007/s11356-017-8904-x.

Ameloot N, De Neve S, Jegajeevagan K, Yildiz G, Buchan D, Funkuin $\mathrm{YN}$, Sleutel S. 2013. Short-term $\mathrm{CO}_{2}$ and $\mathrm{N}_{2} \mathrm{O}$ emissions and microbial properties of biochar amended sandy-loam soils. Soil Biol Biochem 57: 401-410. DOI: 10.1016/j. soilbio.2012.10.025.

Atkinson CJ, Fitzgerald JD, Hipps NA. 2010. Potential mechanisms for achieving agricultural benefits from biochar application to temperate soils: A review. Plant Soil 337: 1-18. DOI 10.1007/s11104-010-0464-5.

Baker JM., Ochsner TE, Venterea RT, Griffis TJ. 2007. Tillage and soil carbon sequestration-What do we really know? Agric Ecosyst Environ 118: 1-5.

Baldock JA, Smernik, RJ. 2002. Chemical composition and bioavailability of thermally altered Pinus resinosa (red pine) wood. Organic Geochemistry 33, 1093-1109.

Becker P. 2006. Special features of tropical heath forest: facts and myths. Tropics 15 (3): 267-270.

Bruun EW, Ambus P, Egsgaard H, Hauggaard-Nielsen H. 2012. Effects of slow and fast pyrolysis biochar on soil $\mathrm{C}$ and $\mathrm{N}$ turnover dynamics. Soil Biol Biochem 46: 73-79. DOI: 10.1016/j.soilbio.2011.11.019.

Budiharta S, Meijaard E, Erskine PD, Rondinini C, Pacifici M, Wilson KA. 2014. Restoring degraded tropical forests for carbon and biodiversity. Environ Res Lett 9: 114020.

Buurman P, Jongmans AG. 2004. Podzolization and soil organic matter dynamics. Geoderma 125: 71-83.

Canellas LP, Olivares FL, Aguiar NO, Jones DL, Nebbioso A, Mazzei P, Piccolo A. 2015. Humicandfulvic acids as biostimulants in horticulture. Sci Hortic 196: 15-27.

Carter S, Shackley S, Sohi S, Suy TB, Haefele S. 2013. The impact of biochar application on soil properties and plant growth of pot grown lettuce (Lactuca sativa) and cabbage (Brassica chinensis). Agronomy 3 (2): 404-418. DOI: 10.3390/agronomy3020404.

Chan KY, Van Zwieten L, Meszaros I, Downie A, Joseph S. 2007. Agronomic values of greenwaste biochar as a soil amendment. Aust J Soil Res 45: 629-634

Chapin III FS, Bloom AJ, Field CB, Waring RH. 1987. Plant Responses to Multiple Environmental Factors: Physiological ecology provides tools for studying how interacting environmental resources control plant growth. BioScience 37 (1): 49-57.

Chen G, Wang S, Huang X, Hong J, Du L, Zhang L, Ye L. 2015. Environmental factors affecting growth and development of Banlangen (Radix Isatidis) in China. Afr J Plant Sci 9 (11): 421-426.

Chen WJ, Chen JM, Price DT, Cihlar J, Liu J. 2000. Carbon offset potentials of four alternative forest management strategies in Canada: a simulation study. Mitig Adapt Strat Global Ch 5: 143-169.

Cornelissen G, Martinsen V, Shitumbanuma V, Alling V, Breedveld GD, Rutherford DW, et al. 2013. Biochar effect on maize yield and soil characteristics in five conservation farming sites in Zambia. Agronomy 3: 256-274. DOI: 10.3390/agronomy3020256.

Darusman, Syahruddin, Syakur, Manfarizah. 2017. Biochar and Tillage Systems Influenced on Soil Physical Properties. Aceh Intl J Sci Technol 6 (2): 68-74. DOI: 10.13170/aijst.6.2.8439.

Davies SJ, Becker P. 1996. Floristic composition and stand structure of mixed dipterocarp and heath forests in Brunei Darussalam. J Trop For Sci 8: 542-569.

DeLuca T, MacKenzie M, Gundale M. 2009. Biochar effects on soil nutrient transformations. In: Lehmann J, Joseph S (eds.). Biochar for Environmental Management, Science and Technology. Earthscan, London, UK. DOI: 10.4324/9781849770552.

Dharmakeerthi RS, Chandrasiri JAS, Edirimanne VU. 2012. Effect of rubber wood biochar on nutrition and growth of nursery plants of Hevea brasiliensis established in an ultisol. SpringerPlus 1: 84 .

Dixon RK, Winjum JK, Schroeder PE. 1993. Conservation and sequestration of carbon: the potential of forest and agroforest management practices. Global Environ Ch 3 (2): 159-173.

Dordas CA, Lithourgidis AS, Matsi T, Barbayiannis N. 2007. Application of liquid cattle manure and inorganic fertilizers affect dry matter, nitrogen accumulation, and partitioning in maize. Nutr Cycl Agroecosyst 80: 283-296.

Egamberdieva D, Reckling M, Wirth S. 2017. Biochar-based Bradyrhizobium inoculum improves growth of lupin (Lupinus angustifolius L.) under drought stress. Eur J Soil Biol 78: 38-42.
Farhangi-Abriz S, Torabian S. 2017. Biochar increased plant growthpromoting hormones and helped to alleviates salt stress in common bean seedlings. J Plant Growth Regul. DOI: 10.1007/s00344-0179756-9.

Fernandes JD, Chaves LHG, da Silva Mendes J, de Brito Chaves I, Tito GA. 2018. Soil chemical amendments and the macronutrients mobility evaluation in Oxisol treated with biochar. J Agric Sci 10 (10): 238-247.

Fisher R. 1919. XV.-The correlation between relatives on the supposition of mendelian inheritance. Trans R Soc Edinburgh 52 (2): 399-433. DOI: $10.1017 / \mathrm{S} 0080456800012163$.

Fisher RA. 1935. The Design of Experiments. Oliver \& Boyd, Edinburgh.

Freixo AA, Machado PL, Santos HP, Silva CA, Fadigas FS. 2002. Soil organic carbon and fractions of a Rhodic Ferralsol under the influence of tillage and crop rotation systems in southern Brazil. Soil Till Res 64: $221-230$.

Gartler J, Robinson B, Burton K, Clucas L. 2013. Carbonaceous soil amendments to biofortify crop plants with zinc. Sci Total Environ 465: 308-313. DOI: 10.1016/j.scitotenv.2012.10.027.

George EF, Hall MA, Klerk GJD. 2008. Stock Plant Physiological Factors Affecting Growth and Morphogenesis. In: George EF, Hall MA, Klerk GJD. (eds.). Plant Propagation by Tissue Culture. Springer, Dordrecht.

Glaser B, Lehmann J, Zech W. 2002. Ameliorating physical and chemical properties of highly weathered soils in the tropics with charcoal: A review. Biol Fertil Soils 35: 219-230. DOI: 10.1007/s00374-0020466-4.

Gondek K, Mierzwa-Hersztek M, Kopeć M, Mróz T. 2018. The influence of biochar enriched with magnesium and sulfur on the amount of perennial ryegrass biomass and selected chemical properties and biological of sandy soil. Commun Soil Sci Plant Anal. DOI: 10.1080/00103624.2018.1455848

Graber ER, Meller-Harel Y, Kolton M, Cytryn E, Silber A, Rav David D. 2010. Biochar impact on development and productivity of pepper and tomato grown in fertigated soilless media. Plant Soil 337: 481-496,

Haider G, Koyro H-W, Azam F, Steffens D, Müller C, Kammann C. 2014. Biochar but not humic acid product amendment affected maize yields via improving plant-soil moisture relations. Plant Soil 395: 141-157. DOI: $10.1007 / \mathrm{s} 11104-014-2294-3$.

Harmon ME. 2001. Carbon sequestration in forests: addressing the scale question. J For 99 (4): 24-29.

Herath H, Camps-Arbestain M, Hedley M. 2013. Effect of biochar on soil physical properties in two contrasting soils: an alfisol and an andisol. Geoderma 209-210: 188-197.

Hossain MK, Strezov V, Chan KY, Nelson PF. 2010. Agronomic properties of wastewater sludge biochar and bioavailability of metals in production of cherry tomato (Lycopersicon esculentum). Chemosphere 78: 1167-1171.

Hou JQ, Li MX, Mao XH, Hao Y, Ding J, Liu DM, Xi BD, Liu HL. 2017. Response of microbial community of organic-matter-impoverished arable soil to long-term application of soil conditioner derived from dynamic rapid fermentation of food waste. PLoS ONE 12: e0175715. DOI: 10.1371/journal.pone.0175715.

Huang W, Ji H, Gheysen G, Debode J, Kyndt T. 2015. Biochar-amended potting medium reduces the susceptibility of rice to root-knot nematode infections. BMC Plant Biol 15: 267-281. DOI: 10.1186/s12870-015-0654-7.

IPCC. 2000. Land Use, Land Use Change and Forestry. In: Watson RT, Noble IR, Bolin B, Ravindranath NH, Verardo DJ, Dokken DJ (eds.). A Special Report of the IPCC, Cambridge University Press, Cambridge, UK

IPCC. 2001. Climate Change 2001: Impacts and Adaptation. Cambridge University Press, Cambridge, MA.

Ji R, Dong G, Shi W, Min J. 2017. Effects of liquid organic fertilizers on plant growth and rhizosphere soil characteristics of Chrysanthemum. Sustainability 9: 841. DOI: 10.3390/su9050841.

Jopony M, Tan YY.1989. Chemical characterization of podzols in Sabah, East Malaysia. Pertanika J Trop Agric Sci 12: 56-63.

Kammann CI, Linsel S, Gößling JW, Koyro H-W. 2011. Influence of biochar on drought tolerance of Chenopodium quinoa Willd and on soil-plant relations. Plant Soil 345: 195-210. DOI: 10.1007/s11104011-0771-5

Kanouo BMD, Allaire SE, Munson AD. 2017. Quality of biochars made from Eucalyptus tree bark and corncob using a pilot-scale retort kiln. Waste Biomass Valor. DOI 10.1007/s12649-017-9884-2. 
Kim HS, Kim KR, Yang JE, Ok YS, Owens G, Nehls T, Wessolek G, Kim KH. 2016. Effect of biochar on reclaimed tidal land soil properties and maize (Zea mays L.) response. Chemosphere 142: 153 159.

Kolton M, Harel YM, Pasternak Z, Graber ER, Elad Y, Cytryn E. 2011 Impact of biochar application to soil on the root-associated bacterial community structure of fully developed greenhouse pepper plants. Appl Environ Microbiol 77: 4924-4930.

Kuzyakov Y, Subbotina I, Chen H, Bogomolova I, Xu X. 2009. Black carbon decomposition and incorporation into soil microbial biomass estimated by 14C labeling. Soil Biol Biochem 41: 210-219.

Lal M, Singh R. 2000. Carbon sequestration potential of Indian forests. Environ Monit Assess 60: 315-327.

Lal R. 2010. Managing soils and ecosystems for mitigating anthropogenic carbon emissions and advancing global food security. Bioscience 60 708-721. DOI: 10.1525/bio.2010.60.9.8.

Lal R. 2003. Global potential of soil carbon sequestration to mitigate the greenhouse effect. Crit Rev Plant Sci 22 (2): 151-184.

Lee J, Morrison IK, LeBlanc J.-D, Dumas MT, Cameron DA. 2002 Carbon sequestration in trees and regrowth vegetation as affected by clearcut and partial cut harvesting in a second-growth boreal mixed wood. For Ecol Manag 169: 83-101.

Lee JJ, Park RD, Kim YW, Shim JH, Chae DH, Rim YS, Sohn BK, Kim TH, Kim KY. 2004. Effect of food waste compost on microbial population, soil enzyme activity and lettuce growth. Bioresour Technol 93: 21-28.

Lehmann J, Gaunt J, Rondon M. 2006. Bio-char sequestration in terrestrial ecosystems: A review. Mitig Adapt Strat Glob Ch 11: 395419. DOI: 10.1007/s11027-005-9006-5.

Lehmann J, Rillig MC, Thies J, Masiello CA, Hockaday WC, Crowley D. 2011. Biochar effects on soil biota: A review. Soil Biol Biochem 43: 1812-1836. DOI: 10.1016/j.soilbio.2011.04.022.

Lehmann J. 2007. A handful of Carbon. Nature 477: 143-144. DOI: $10.1038 / 447143 a$.

Lenton TM, Vaughan NE. 2009. The radiative forcing potential of different climate geoengineering options. Atmos Chem Phys Discuss 9: 2559-2608.

Liang B, Lehmann J, Solomon D, Kinyangi J, Grossman J, O’Neill B, Skjemstad JO, Thies J, Luizão FJ, Petersen J, Neves EG. 2006. Black carbon increases cation exchange capacity in soils. Soil Sci Soc Am J 70: 1719-1730. DOI: 10.2136/sssaj2005.0383.

Liu A, Tian D, Xiang Y, Mo H. 2016. Biochar improved growth of an important medicinal plant (Salvia miltiorrhiza Bunge) and inhibited its cadmium uptake. J Plant Biol Soil Health 3 (2): 1-6.

Lu WW, Ding WX, Zhang JH, Li Y, Luo JF, Bolan N, Xie ZB. 2014 Biochar suppressed the decomposition of organic carbon in a cultivated sandy loam soil: A negative priming effect. Soil Biol Biochem 76: 12-21. DOI: 10.1016/j.soilbio.2014.04.029

Luo F, Song J, Xia WX, Dong MG, Chen MF, Soudek P. 2014 Characterization of contaminants and evaluation of the suitability for land application of maize and sludge biochars. Environ Sci Pollut Res Intl 21: 8707-8717. DOI: 10.1007/s11356-014-2797-8

Mahmoud EK, El-Beshbeshy TR, Abd El-Kader NE, El Shal R, Khalafallah N. 2017. Biochar impacts on physical properties and wheat yield of salt-affected soils. Intl J Res Sci Publ 2 (1): 1-10.

Major J, Rondon M, Molina D, Riha SJ, Lehmann J. 2010. Maize yield and nutrition during 4 years after biochar application to a Colombian savanna oxisol. Plant Soil 333: 117-128.

Marjenah, Kiswanto, Purwanti S, Sofyan FPM. 2016. The effect of biochar, cocopeat and sawdust compost on the growth of two dipterocarps seedlings. Nusantara Biosci 8 (1): 39-44.

Marland G, Schlamadinger B. 1999. The Kyoto Protocol could make a difference for the optimal forest-based $\mathrm{CO}_{2}$ mitigation strategy: some results from GORCAM. Environ Sci Pol 2: 111-124.

Mehari ZH, Elad Y, Rav-David D, Graber ER, Harel YM. 2015. Induced systemic resistance in tomato (Solanum lycopersicum) against Botrytis cinerea by biochar amendment involves jasmonic acid signaling. Plant Soil 395: 31-44. DOI: 10.1007/s11104-015-2445-1.

Metting FB, Smith JL, Amthor JS, Izaurralde RC. 2001. Science needs and new technology for increasing soil carbon sequestration. Climatic Change 51: 11-34

Montagnin F, Porras C. 1998. Evaluating the role of plantations as carbon sinks: an example of an integrative approach from the humid tropics. Environ Manag 22: 459-470.
Mukome FN, Zhang X, Silva LC, Six J, Parikh SJ. 2013. Use of chemical and physical characteristics to investigate trends in biochar feedstocks. J Agric Food Chem 61: 2196-2204.

Ney RA, Schnoor JL, Mancuso MA. 2002. A methodology to estimate carbon storage and flux in forestland using existing forest and soils databases. Environ Monit Assess 78: 291-307.

Palumbo AV, Mccarthy JF, Amonette JE, Fisher LS, Wullshleger SD, Daniels WL. 2004. Prospects for enhancing carbon sequestration and reclamation of degraded lands with fossil-fuel combustion byproducts. Advan Environ Res 8: 425-438.

Papadopol CS. 2000. Impacts of climate warming on forests in Ontario: options for adaptation and mitigation. For Chron 76: 139-149.

Pelley J. 2003. Taking credit for forest carbon sinks: Is the policy getting ahead of the science? Environ Sci Technol 37 (3): 58A-63A. DOI: $10.1021 / \mathrm{es} 032368 \mathrm{c}$

Prasetyo BH, Sulaeman Y, Subardja D, Hikmatullah. 2006. Characteristics of spodosols in relation to land management in Kutai Kertanegara, East Kalimantan. Jurnal Tanah dan Iklim 24: 69-79. \{Indonesian]

Pratiwi EPA, Shinogi Y. 2016. Rice husk biochar application to paddy soil and its effects on soil physical properties, plant growth, and methane emission. Paddy Water Environ 14: 521-532. DOI: 10.1007/s10333-015-0521-z.

Ravindranath NH, Somashekhar BS, Gadgil M. 1997. Carbon flow in Indian forests. Clim Ch 35: 297-320.

Rees F, Germain C, Sterckeman T, Morel J-L. 2015. Plant growth and metal uptake by a non-hyperaccumulating species (Lolium perenne) and a Cd-Zn hyperaccumulator (Noccaea caerulescens) in contaminated soils amended with biochar. ICOBTE 2015, Fukuoka, Japan.

Reijnders L. 2009. Are forestation, bio-char and landfilled biomass adequate offsets for the climate effects of burning fossil fuels? Energy Pol 37: 2839-2841.

Rizwan M, Ali S, Qayyum MF, Ibrahim M, Zia-ur-Rehman M, et al. 2015. Mechanisms of biochar-mediated alleviation of toxicity of trace elements in plants: a critical review. Environ Sci Pollut Res 23: 22302248. DOI: 10.1007/s11356-015-5697-7.

Rondon M, Ramirez JA, Lehmann J. 2005. Charcoal additions reduce net emissions of greenhouse gases to the atmosphere. Paper read at Proceedings of the 3rd USDA Symposium on Greenhouse Gases and Carbon Sequestration, March 21-24 2005, in Baltimore, USA.

Roslan I, Shamshuddin J, Fauziah CI, Anuar AR. 2010. Occurrence and properties of soils on sandy beach ridges in the Kelantan-Terengganu Plains, Peninsular Malaysia. Catena 83: 55-63.

Roslan I, Shamshuddin J, Fauziah CI, Anuar AR. 2011. Fertility and suitability of the spodosols formed on sandy beach ridges interspersed with swales in the Kelantan-Terengganu plains of Malaysia for kenaf production. Malaysian J Soil Sci 15: 1-24.

Sampson RN, Sedjo RA. 1997. Economics of carbon sequestration in forestry: an overview. Crit Rev Environ Technol 27: S1-S8.

Sauerbeck DR. 2001. $\mathrm{CO}_{2}$ emissions and $\mathrm{C}$ sequestration by agricultureperspectives and limitations. Nutr Cycl Agroecosyst 60: 253-266.

Schimel DS, House JI, Hibbard KA, Bousquet P, Ciais P, Peylin P, Braswell BH, Apps MJ, Baker D, Bondeau A, Canadell J, Churkina G, Cramer W, Denning AS, Field CB, Friedlingstein P, Goodale C, Heimann M, Houghton RA, Melillo JM, Moore III B, Murdiyarso D, Noble I, Pacala SW, Prentice IC, Raupach MR, Rayner PJ, Scholes RJ, Steffen WL, Wirth C. 2001. Recent patterns and mechanisms of carbon exchange by terrestrial ecosystems. Nature 414: 169-172.

Schimel DS. 1995. Terrestrial ecosystems and the carbon cycle. Global Ch Biol 1: 77-91

Schimmelpfennig S, Müller C, Grünhage L, Koch C, Kammann C. 2014. Biochar, hydrochar and uncarbonized feedstock application to permanent grassland-effects on greenhouse gas emissions and plant growth. Agric Ecosyst Environ 191: 39-52.

Schulz H, Glaser B. 2012. Effects of biochar compared to organic and inorganic fertilizers on soil quality and plant growth in a greenhouse experiment. J Plant Nutr Soil Sci 175: 410-422. DOI: 10.1002/jpln.201100143.

Sharp RG. 2013. A review of the applications of chitin and its derivatives in agriculture to modify plant-microbial interactions and improve crop yields. Agronomy 3: 757-793.

Silber A, Levkovitch I, Graber ER. 2010. pH-dependent mineral release and surface properties of corn straw biochar: agronomic implications. Environ Sci Technol 44: 9318-9323. 
Smith P, Davis SJ, Creutzig F, Fuss S, Minx J, et al. 2016. Biophysical and economic limits to negative $\mathrm{CO}_{2}$ emissions. Nat Clim Ch 6: 4250. http: //dx.doi.org/10.1038/nclimate2870.

Soerianegara I, Lemmens RHMJ. 1993. Plant Resources of South-East Asia 5 (1): Timber trees: major commercial timbers. Pudoc Scientific Publishers, Wageningen, Belanda.

Soil Survey Staff. 1996. Keys to soil taxonomy. U.S. Gov. Print. Office, Washington DC.

Spokas KA, Koskinen WC, Baker JM, Reicosky DC. 2009. Impacts of woodchip biochar additions on greenhouse gas production and sorption/degradation of two herbicides in Minnesota soil. Chemosphere 77: 574-581.

Steiner C, Teixeira WG, Lehmann J, Nehls T, Macêdo JLV, Blum WEH, Zech W. 2007. Long term effects of manure, charcoal and mineral fertilization on crop production and fertility on a highly weathered Central Amazonian upland soil. Plant Soil 291: 275-290. DOI: 10.1007/s11104-007-9193-9.

Sun D, Meng J, Liang H, Yang E, Huang Y, et al. 2015. Effect of volatile organic compounds absorbed to fresh biochar on survival of Bacillus mucilaginosus and structure of soil microbial communities. J Soils Sedim 15: 271-281. DOI: 10.1007/s11368-014-0996-z.

Syahrinudin S, Wijaya A, Butarbutar T, Hartati W, Ibrahim I, Sipayung M. 2018. Biochar produced by retort closed drum kiln promotes higher plant growth rate. ULIN: Jurnal Hutan Tropis 2 (1). DOI: 10.32522/u-jht.v2i1.1291. [Indonesian]

Thies J, Rillig MC. 2009. Characteristics of biochar: Biological properties. In: Lehmann J, Joseph S (eds.). Biochar for environmental management: Science and technology. Earthscan, London.

Vasicek O. 1976. A Test for normality based on sample entropy. J R Stat Soc B Method 38 (1): 54-59.

William K, Qureshi RA. 2015. Evaluation of biochar as fertilizer for the growth of some seasonal vegetables. J Bioresour Manag 2 (1): 41-46.
Wilson MA, Righi D. 2010. Spodic horizon. In: Stoops G, Marcelino V, Mees F. (eds.). Interpretation of Micromorphological Features of Soils and Regoliths. Elsevier, New York.

Woolf D, Amonette JE, Street-Perrott FA, Lehmann J, Joseph S. 2010. Sustainable biochar to mitigate global climate change. Nature Commun 1 (5). DOI: 10.1038/ncomms1053.

Xu R, Zhao AZ, Yuan JH, Jiang J. 2012. pH buffering capacity of acid soils from tropical and subtropical regions of China as influenced by incorporation of crop straw biochars. J Soil Sedim 12: 494-502.

Yanai Y, Toyota K, Okazaki M. 2007. Effects of charcoal addition on $\mathrm{N}_{2} \mathrm{O}$ emissions from soil resulting from rewetting air-dried soil in short-term laboratory experiments. Soil Sci Plant Nutr 53 (2): 181188.

Yu L, Yu M, Lu X, Tang C, Liu X, Brookes PC, Xu J. 2018. Combined application of biochar and nitrogen fertilizer benefits nitrogen retention in the rhizosphere of soybean by increasing microbial biomass but not altering microbial community structure. Sci Total Environ 640-641: 1221-1230. DOI: 10.1016/j.scitotenv.2018.06.018.

Yuan JH, Xu RK, Qian W, Wang RH. 2011. Comparison of the ameliorating effects on an acidic Ultisol between four crop straws and their biochars. J Soil Sedim 11: 741-750.

Zheng RL, Cai C, Liang JH, Huang Q, Chen Z, Huang YZ, Sun GX. 2012. The effects of biochars from rice residue on the formation of iron plaque and the accumulation of $\mathrm{Cd}, \mathrm{Zn}, \mathrm{Pb}$, As in rice (Oryza sativa L.) seedlings. Chemosphere 89: 856-862. DOI: 10.1016/j.chemosphere.2012.05.008.

Zhu Z, Zhang FG, Wang C, Ran W, Shen QR. 2013. Treating fermentative residues as liquid fertilizer and its efficacy on tomato growth. Sci Hortic 164: 492-498.

Zong Y, Chen D, Lu S. 2014. Impact of biochars on swell-shrinkage behavior, mechanical strength, and surface cracking of clayey soil. J Plant Nutr Soil Sci 177: 920-926. 